\title{
Implementation Mechanism of Ethics in Business Organizations
}

\author{
Dr. Md. Abdul Jalil \\ Department of Business Administration, Faculty of Economics and Management \\ International Islamic University, Malaysia (IIUM) \\ E-mail: abduljalil@iiu.edu.my, abd_jali12@yahoo.com \\ Ferdous Azam \\ Department of Business Administration, Faculty of Economics and Management \\ International Islamic University (IIUM), Malaysia \\ E-mail: sakeebferdous@gmail.com \\ Muhammad Khalilur Rahman \\ Department of Business Administration, Faculty of Economics and Management \\ International Islamic University (IIUM), Malaysia \\ E-mail: abd_khalil2@yahoo.com
}

\begin{abstract}
Ethics and ethical behavior are issues which are increasingly being focused on the business community today. People are becoming more concerned about what is actually happening in business organizations in the name of competition, growth, and profitability. Organizations are crossing the red zone of ethics and ethical behaviors. A growing number of organizations are constantly surveying and evaluating the unethical practice in business organizations worldwide. The purpose of this paper is to examine the importance of ethical practices and how to implement those ethical practices in business organizations. It is empirically proved that ethical practices in business organizations help to create favorable relationships with other organizations and can also establish long-term positive relationships with existing and potential future customers. Descriptive and analytical research methodology is applied in this research paper. The findings of this paper is that it is very essential to have a code of business ethics in every business organization and this code of business ethics must be implemented in the organization in objective and effective way.
\end{abstract}

Keywords: Ethics, Business Organizations, Code of Ethics, Ethics in Islamic law, Customer Satisfaction, Customer Loyalty

\section{Introduction}

At the present time, governments and stakeholders in business organizations are emphasizing on the code of business ethics. Business ethics managers also do not deny the importance of having a code of business ethics to be complied with by the employees of business organizations. Every year many cases of unethical practices take place in different business organizations world wide. That is why academic scholars and corporate practitioners are also worried about the increasing number of unethical practices occurring in business organizations.

Academic scholars are writing a lot of books on business ethics and asking business managers to practice themselves and to implement those ethical principles in their organizations. Universities in almost all countries in the world are teaching 'business ethics' as a compulsory or elective course to their students. They believe that today's students are future managers and executives of different business organizations. So, they should know the importance of business ethical principles starting from their student life.

Governments of different countries are either preparing a code of business ethics and asking business organizations or associations to implement it properly among employees or asking business organizations to prepare their own code of business ethics and to implement it in their organizations properly. The later is known as self-regulation and implementation of business ethics in business organizations on their own initiative. But the best way to implement business ethics is for the government to prepare a code of business ethics in consultation with the association of business organizations and asking them to implement those ethical principles effectively and completely. The government should have a monitoring branch to monitor the implementation of the ethical principles in business organizations and if needed to take legal action against business organizations which do not 
implement the code of business ethics or show negligence in implementing (of - delete) business ethics. So, the monitoring branch should have legal powers to impose penal provisions under subsidiary laws.

Unethical practices in business organizations cause enormous harm to stakeholders of business organizations. The best example is the sub-prime loans given to borrowers in the US in 2008 which brought down the economy of the US and also badly affected the economy of the whole world (Ebrahim, 2008; Siddiqi, 2008). The economy of the whole world suffered from serious economic slow down, thousands of employees became unemployed, and investors lost billions of dollars and so on.

It is very important that business organizations practice universal business ethical principles to ensure the best practice and best governance in business organizations. Proper implementation of business ethics in organizations can ensure maximization of lawful profits and effectively protect the interests of all stakeholders of business organizations including corporate social responsibility of business organizations about which much has been said and written by academic scholars (Sealy, 1987, 2001; Petrini and Pozzebon, 2009; Blumberg, 1970; Machan 2009). This eventually can ensure a viable and competitive business environment worldwide and such a viable and completive business practice is very much needed in the world of business as well as in the capital market. The authors sincerely believe that preparing and implementing a code of business ethics is of paramount importance in the business and capital market in the world at the present time as well as for the future. The contents of business ethics may vary from country to country. However, we believe that there are some universal ethical business principles which all the countries in the world should incorporate in their code of business ethics. As stated in the abstract, descriptive and analytical research methodology is applied in this research to discuss the importance of having a code of business ethics and a mechanism to properly implement the code of business ethics within business organizations. The overall objectives of this research paper are:

(1) To determine the importance of ethical behavior in business organizations.

(2) To determine the possible contents of a code of business ethics;

(3) To recommend ways how to implement this code of ethics in the business organizations.

\section{Literature Reveiw}

\section{Ethics and business ethics}

The word 'ethic' comes from the Greek word ethos, which means "the character, custom or a set of moral behavior that is accepted extensively." According to Solomon (1984), the etymology of ethics suggests its basic concerns are: (1) individual character, including what it means to be "a good person," and (2) the social rules that govern and limit our conduct, especially the ultimate rules concerning right and wrong, which we call morality. Ethics also can be defined as the conception of what is right and fair conduct or behavior (Carroll, 1991; Freeman and Gilbert, 1988). Ethics is the concept of morals; one's ability to choose between right and wrong, good and bad, acceptable and unacceptable (Desjardins, 2009; Valasquez, 2009).

The concept of 'Business Ethics' has come to mean various things to various people. Velasquez (2009) identified business ethics as a specialized study of moral right and wrong; whereas Garrett (1970) defined business ethics as the relationship of business goals and techniques to specifically human ends. It studies the impacts of acts on the good of the individual, the firm, the business community, and society as a whole. According to Weihrich and Koontz (1994), business ethics is concerned with truth and justice and has a variety of aspects such as the expectations of society, fair competition, advertising, public relations, social responsibilities, consumer autonomy, and corporate behavior in the home country as well as abroad. Business ethics is the standard of conduct and moral values governing actions and decisions in the work environment (Boone and Kurtz, 2005) and it is based on broad principles of integrity and fairness and focuses on stakeholders' issues such as product quality, customer satisfaction, employee wages and benefits and local community and environmental responsibilities. In business organizations, managers debate on this issue because there is no single satisfactory standard of ethical action agreeable to everyone that a manager can use to make specific operational decisions (Laczniak, 1983). However, there are people who see business ethics as important as the profit the organization derives. Besides, many people believe that talking about ethics, values, integrity, fairness is not only acceptable in the business community but it is practically required (Stodder, 1998). Consequently, management practitioners should continue to focus attention on the ethics climate in their organizations because of their unique responsibilities. Ethical considerations conspicuously affect business organizations of all sizes as they affect all forms of human activity. A question exists, however, concerning similarities and differences in the ethical concerns and attitudes prevailing in large and small companies. 


\section{Contents of business ethics}

'Ethics' can be understood in Islamic terms as haya, the state of respect and practice of good deeds. Islam provides a climate of work within which ethics is not separated from economics. Islamic ethical principles determine individual choices, based not only on profit maximization, but also on the maximization of social welfare (Pramanaik, 1994). So as a Muslim, ethics should be reflected on each Muslim's behavior in every aspect of his or her life, meaning that, we have to internalize the ethics. The internalization of ethics involves knowledge of ethical practices in a business organization; awareness of those ethical principles which are to be transferred and internalized, expertise in the internalization of ethics, and knowledge of relevant laws (Rizk, 2008). The internalization of Islamic ethical practices strengthens certain qualities; such as honesty, trust, solidarity, loyalty and flexibility. Accordingly, when Arabs internalized the principles of Islam, that strengthened cooperation among themselves and their achievements were great at that time. Rahman (1996) focused on Islamic basic ethical principles in the work place. According to him "One aspect is to recruit those who are most likely to have values and virtues. This dimension requires a stringent screening mechanism. Another aspect consists of continual on-the-job-education in the aforementioned values and virtues. One incentive mechanism is to keep an employee well-paid; another is to appoint an employee on a probationary basis, until values and virtues in question have been internalized" (Rahman, 1996).

Morals can either be classified as secular or religious. Secular morality tries to establish a moral system that is independent of God and religious faiths. In terms of motives for morality, various explanations have been given. One explanation is that people are ethical in pursuit of happiness or perfection. Another suggests that pressure by political power or social means forces people to follow a certain code of conduct. Yet another explanation is that a feeling of duty makes people moral. As for religious morality, it is derived from the revealed knowledge sent down by God to people through His messengers (Prophets) throughout the ages. Religious morality is fundamentally based on two things: first is the belief in God as the Creator of the universe, and second is the belief in the Hereafter. One thing that should be noted is that religious morality is not uniform across religions and it significantly differs among world religions, so the fundamentals of religious morality are not the same for all religions. That is why the ethical theory of relativism says that moral and ethical principles are not same between societies and religions (Pheng and Detta, 2009). Moral principles can vary from one society to another society. For example, in Muslim society taking interest on loan given to people is prohibited (Al-Quran, Sura Baqara, 2:175), but it is not prohibited in non-Muslim societies.

Business Ethics can guide the managers and executives of a business organization in the right direction. It increases the reputation of the business organization, ensures its continuous development and helps to achieve customer satisfaction. The possible contents of business ethics are wide and varied. Some of them might be universally accepted and some might not be universally recognized as business ethics. However, all of them can positively impact the progress of the business organization. The possible contents of business ethics are:

\section{i) Speaking the truth about quality, quantity and ingredients in the product;}

Islamic law (Shariah) orders all human kind including the Muslims to speak the truth all the time including in business. In this regard Al-Quran narrates in Surah Al Maidah (Sura No. 5, verse 119) that in the Day of Qiamah (the Last Day of this world) Allah (God) will say to all human beings: "This is a day on which the truthful will profit from their truth. For them there are Gardens, with rivers flowing beneath, it is their eternal home, Allah is well-pleased with them, and they will be pleased with Him and that will be the great salvation for human beings." This verse of Al-Quran clearly states the reward that will be given to the truthful men including honest and truthful businessmen.

Prophet Muhammad (peace be upon him) said in a hadith (a statement of Prophet Muhammad) that in the Day of Qiamah, Allah (God) will not talk, look at and pardon those sellers (of goods) who falsely swear about the quality of their products so that buyers will buy a large quantity of their goods. (Sahih Muslim Hadith Book). This hadith clearly prohibits swearing falsely to the customers about the quality of the product a businessman is selling. In another hadith Prophet Muhammad said, "The truthful businessmen will remain with prophets, pious men and martyrs in the Day of Qiamah”. (Sahih Tirmidhi Hadith Book).

In another hadith, Prophet Muhammad was asked about great sins and he said: The following are acts of great sin; (a) to join others in worship with Allah; (b) to be undutiful to one's parents; (c) to kill a person (without good reason and without any sanction from court of law); and (d) to give false witness against any person. (Sahih Bukhari Hadith Book, Vol. 3, Hadith No. 821). We can emphasize on point (d) of this hadith which says that it is a great $\sin$ to give false witness against any person. In business transactions, disputes may arise and a person may 
give false witness for a businessman in regard to the quality, quantity or the delivery date of the goods. Giving such false evidence in business is a great sin under Islamic law. It is also prohibited for a businessman to tell a lie to potential customers about the quality, quantity, size etc. of the products to be sold.

\section{ii) It is not allowed in Islamic religion to exaggerate the size and quality of products.}

In this regard the prophet Muhammad (peace and blessings be upon him) said that false swearing about the quality of products may increase sales temporarily, but Allah blots out blessing from the seller. (Sahih Bukhari Hadith Book). Businessmen frequently swear falsely about the quality of their products. Such a practice is very bad, it deceives the customers. Therefore, Islam has prohibited it.

iii) Not cheating customers by false or misleading information about the product.

One day prophet Muhammad (s.w.t) visited a village market (bazaar). He saw a seller selling wheat from a pile. He put his hand into the pile from top of it and felt moisture in the wheat. He asked the seller about the reason for the moisture. The seller replied that some of the grain was damaged by water and so he put it at the bottom of the pile so that customers could not see it. The Prophet said, "It is not allowed. You are cheating the customers. You should put the deteriorated grain on top of the pile so that customers can see it." Finally he said, "He who cheats customers and others is not among the true believers of Allah." (Sahih Tirmidhi Hadith Book)

iv) Not concealing the defect in the products;

It is prohibited in Islamic ethical teaching to conceal any defects in the goods which a seller is selling. In this regard Prophet Muhammad said: "It is not permissible to sell an article without disclosing defects in the goods nor it is permissible for any one to knowingly conceal defects in the goods." (Baihaqi Hadith Book). In another hadith Prophet said, "Sell the good and bad separately. He who deceives people, he is not among us (true Muslims)." (Sahih Muslim Hadith Book)

\section{v) Giving correct weight and measurement while selling}

Allah (God) says in Sura Al-Mutafiffin (Sura No. 83: Verses 1- 3) that "Woe to those who deal in fraud, those who when they have to receive by weight or measure from men, they exact full weight or measure; but when they have to give by weight or measure to men, they give less than due." In another verse in Al-Quran, Allah says: "Give correct measure whenever you measure, and weigh with a balance that is true; this is good for you and best in the end." (Quran, 17:35)

In Sura Al-Araf (Sura 7, verse 85), Allah says, "Give just measure and weight, do not withhold from the people the things that are their due, and do no mischief on the earth after it has been set in order. That will be best for you, if you have faith in Allah." So, this verse from the Holy Quran emphasizes honest business and providing correct weights and measures to customers.

In Sura Ar-Rahman (Verse 9) Allah orders mankind: "Establish weight with justice and fall not short in the balance." In another verse He also commands sellers "Give correct measure and correct weight in justice." (Al-Quran, 6:152).

\section{vi) Becoming loyal on the owner of business and following his instructions;}

Business agents including managers must be loyal to the owner of the business. They should conduct business honestly and for the benefit of the owner. They must not work for their personal interest while using their position as agent or director. They should not take bribes or commissions from others without the knowledge of the principal.

\section{vii) Obeying the commands of managers and following their instructions;}

It is the ethical duty of all sub-ordinate employees in a business enterprise to obey the commands of managers and to follow their instructions related to conducting business. This is crucial because for the smooth running of the business enterprises and to make a handsome profit in the business, the employees must be loyal to the managers and must cooperate with them with full commitment and skill. If this does not happen, the business cannot prosper.

viii) Managers should value and appreciate suggestions and good performance of executive and subordinate employees;

As the employees have duty to be loyal to the managers, similarly the managers have ethical duty to value and appreciate the good performance of executives and subordinate officers in the business enterprises. This is crucial because there must be excellent relations between the managers and the subordinate officers. The subordinate officers should not be treated in such a way that they feel they are not given proper attention and their opinions and suggestions are not properly valued and taken into consideration in making decision. Besides, the subordinate 
officers sometimes know better than the managers on certain matters about what is good and what is bad for the business enterprises. So, managers should seek suggestions from subordinate officers.

ix) Managers should consult with the subordinate employees while making decision.

Islam emphasizes mutual consultation when making a decision. According to the teachings of al-Quran and Sunnah, leaders must consult followers when making a decision. Allah says in the Holy Quran, "They make decisions by mutual consultation" (Surah Ash-Shura, 42, verse 38). The prophet Muhammad always consulted with his companions before making a decision whether it was related to business, politics, state matter, war, international relation etc. After his death, the four rightly guided Khalifas (elected presidents) followed this consultation mechanism before making any important decisions related to state affairs during their reign from the middle of the $7^{\text {th }}$ century to the $8^{\text {th }}$ century A.D.

They also practiced this consultation policy in their family life to ensure good family relations among family members. However, leaders are not always bound to follow all the suggestions given by their subordinates if they think that other considerations are more important. Besides, certain confidential matters may not be shared with subordinate employees and managers may keep them secret. They can then decide on them and may ask the subordinate executives to implement them. So, after consultation, the managers can decide what decision would be in the business' best interest. This will encourage the subordinate employees to work hard and sincerely for the benefit of business organization.

$\mathrm{x}$ ) Giving incentives and promotions to employees who work hard and sincerely for the business organization and provide innovative ideas for the betterment of the business and gaining competitive edge (advantage) over the competitors (Desjardins, 2009; Valesquez, 2009);

\section{xi) Providing reasonable salary and other benefits to the employees'}

The employees should be given a reasonable salary. Some of the employees perform very well in the business. They act sincerely and honestly. Managers should appreciate them, should promote them to higher position and should also increase their salary and allowances. Such a practice undoubtedly will be beneficial for the business enterprises (David, 1989, 1991; David and David, 2009; Lamb et al, 1984; Morden, 2004; Pettinger, 2007; Render 1992).

xii) Fixing minimum wage for different class of employees;

If we survey the wages in developing countries and even in some developed countries we will find that the lower level workers are given a much lower salary although they are doing very hard work and their work is very significant for productivity in business and in the GDP growth of the country (Desjardins, 2009; Valesquez, 2009).

xiii) Providing healthy and safe environment for the employees in the workplace;

Some work places are very unhealthy for employees. So, managers must take care of those matters and must follow the national law to improve health and safety (De Gorge, 2010; Ghillyer, 2010).

xv) Providing medical treatment facilities and accident benefits in the workplace.

We may have seen that some workplaces are dangerous for the employees to work. They may contact contagious diseases due workplace conditions or due to the nature of the work. The work might be very risky for physical safety and they may be involved in accidents and suffer physical injury including death. Employers should have compulsory health insurance for employees in such work places (Lawrence, 2010; Brenkert, 2010).

xiv) Behaving well with customers. The employees should try to smile while talking and dealing with customers. Good behavior and good manner can conquer the heart of customers which eventually increase sell. (Stanwick, P.A., 2009; Beauchamp et al, 2009; Mukherjee, 2009; Schemerhorn, 2009).

xv) Maximizing the profit of business organization whilst complying with honesty, truthfulness and fairness in business activities (Tirmidi hadith book);

xvi) Maintaining corporate social responsibility, such as protecting the environment, providing financial assistance in overcoming national loss due to natural disaster, such as earthquake, cyclone, tsunami, war, pandemic disease etc (Fukukawa, 2010; Malin, 2010).

xvii) Providing proper and complete labeling on the product or its package. The label should include all the ingredients the product contains, the price and other relevant information [Consumer Protection Act 2006 (Bangladesh); Consumer Protection Act 1999 (Malaysia)].

This list of business ethics is not exhaustive. There may have many more business ethics which the business organizations and their employees should follow. 


\section{Ethics and external customers}

External customers are not a part of an organization, but they greatly influence the organization's activities. External customers can be defined as the ones who purchase, use and influence the sale of products or services of a company. Perception of external customers is very important to the organization. They perceive the organization's ethical value is a significant image in the business world. Investors may decide to invest due to the reputation and ethical behavior of the company in the society (Holme, 2008). Consultants have found this niche and now scan and index the ethical behavior and principles of major international firms. This is a service relied upon by many financing firms when choosing a particular company in which to invest (Lindfelt, 2004).

So, it is a necessity to implement ethical practices in the organization to sustain in this global market. Clear ethical values create trust in the company, both internally and externally. Besides, trust is a two way street and also suppliers will be looking to supply to organizations that they can trust (Holme, 2008). Thus, the higher the level of trust that a company can build with the suppliers, the better the relationship and the better the business reputation that can be established. The interest in business ethics, corporate governance, sustainable business practice, and integrity has grown markedly in the past decades (Waddock et al., 2002). As a number of unethical business practices have been reported in newspapers and these scandals are reducing the confidence level of not only the shareholder but also other stakeholders; ethical practices have become the most significant solution to the problem. Ethical practices help organizations create values in business practices. That value helps organizations to develop relations with different types of institutional actors.

\section{Ethics and internal customers}

'Internal customers' means the employees of the organization: for example, employees from other departments are considered as internal customers, they break down departmental barriers. Fundamentally, an internal customer is anyone we count on or rely upon to complete a task or a function or to provide us with information so that we can get our job done, and anyone who counts on us to complete a task or function or to provide them with information so that they can get their job done. Employee satisfaction is one of the key elements to be a successful organization in the modern market. Job satisfaction is a crucial element in the business success of organizations and in the provision of quality service to customers (Whitehead, 1998).

Employee dissatisfaction leads to employee turnover, absenteeism, and affects employee motivation which in turn affects the quality of the work. Organizational ethics can help to enhance job satisfaction and organizational commitment, which can in turn reduce absenteeism and turnover (Hian and Boo, 2004). It is not only the stakeholders who expect companies to pay greater attention to norms, values, and principles but companies themselves are also acknowledging the importance of responsible business practices (Waddock et al., 2002). Employees look more to the broader organizational environment than to their particular role in attributing their satisfaction to their job (Leigh et al., 1988). Ethical values would suggest something much more than a legal minimum, the management behaviors would be more subtle than those required by the law. Employees who feel a strong alignment with the organization's values and know that they are supported can react with strong motivation and performance which is crucial to customer approval (Holme, 2008).

\section{Implementation of ethics in business organizations}

The code of ethics can demonstrate and reinforce the top management's support for ethical behavior and help develop a favorable ethical climate and culture in the organization and to have the intended effects. It is also important that the code of ethics be communicated, monitored and enforced in business organizations (Hian and Boo, 2004). It is crucial that management shows a dedication to, and materialize the code of ethics. The enforcement of a code of ethics is positively related to show how important employees perceive the role of ethics and social responsibility in achieving long-term organizational effectiveness (Vitell et al., 2003). Favorable organizational ethics produce constructive organizational outcomes.

An organization can embrace an organizational code of ethics by setting down the ethical philosophy, and rules of conduct and practices. The code can enhance corporate reputation and brand image, signal to internal and external parties that the organization is committed to ethical behavior, create a cohesive corporate culture, and guide and influence behavior within the organization (Carasco and Singh, 2003). Besides, an organization may appoint ethics officers to organize employee training programs in ethics. Such programs can provide an effective means of setting and communicating expectations among employees about their actions and behavior. However, top management support can play a major role in ethics training and enforcement of ethical behavior and standards. Likewise, the association between ethical behavior and career success can be incorporated into the corporate culture, which usually encompasses the ways work and authority are organized, the ways people are rewarded and controlled, as well as organizational features such as customs, taboos, company slogans, heroes and social rituals (Brickley et al., 
2002). Joyner and Payne (2002) affirmed that an organization can integrate ethics into the normal channels of strategic decision-making and train managers in decision-making skills that incorporate ethical principles and values.

Ethics is concerned with moral obligation, responsibility, and social justice, whereas self consciousness refers to personal awareness abut something. In a competitive environment, companies are faced with making decisions that often border on illegal or unethical behavior (Gayton, 2008). Most of the cases of unethical behavior appear as the main culprit for company's business development because employee's personal benefit works against it which is unethically obtained. In business ethics there is always a question as to the nature of the actor who bears responsibility (Fisscher and Nijhof, 2005). If the responsible person becomes unethical, it affects the whole system.

It is crucial to implement business ethics in an organization. If the ethics are not implemented not only the customers and other stakeholders will be affected but also the business organization itself will be affected. For resorting to unethical practice, the organization's reputation and good image will be damaged and it will lose its customers. So, the issue is how business ethics can be properly implemented.

Before we discuss the implementation process of business ethics, we need to discuss the need to compile the contents of business ethics into a code of ethics. The issue is: Who will prepare the code of business ethics? There are possible two ways of producing the ethics code; firstly, the government of each country may take the initiative to compile business ethics and put them together in a code of ethics and then require business organizations to implement the code. Secondly, the government may ask the associations of business organizations in a country to prepare a code of business ethics and implement it within their organizations. However, if the code of ethics is prepared by the association of business organizations, it should get approval from the government.

Now, we can discuss the possible ways of implementation of the code of business ethics in business organizations. As it is ethical code, it can not be implemented by bringing legal action in court against the defaulting business organization. However, if the government legislates the code of business ethics in Parliament and provides penalty provisions in it for its implementation, then the code can be implemented by bringing legal action in court. That is the best way to implement the code of ethics. However, some of the ethical contents might not be implemented by force or legal action; they should be left to the business organizations for voluntary implementation. Some important ethical contents have already been made law in different legislations. So, the code of ethics can be implemented by taking legal action in court or by referring to special tribunals or to arbitration process. In that case, the code of ethics may provide both civil and criminal remedy to the affected party. A criminal penalty can only be implemented by the government but a civil remedy can be claimed by the affected stakeholders including customers.

Another way to implement the ethical code is to leave it to organizations to implementation it. Managers will implement the code of ethics in the organization and will monitor whether it is properly being implemented. The organizations can appoint trained ethics officers who will organize training programs on the implementation of the ethical code. The ethics training program can be held twice a year but all the employees cannot attend at the same time. Employees will be selected for the training by turn. So, training groups can be prepared among the employees who will be trained in turn. The managers must monitor regularly whether the code of ethics is being implemented and complied with by each and every employee from top level to the bottom in ranking of the employees in the organization.

Bixler (2002) explains the importance of organizational learning as follows:

"Organizational learning must be addressed with approaches such as increasing internal communications, promoting cross-functional teams and creating a learning community. Learning is an integral part of knowledge management. In this context, learning can be described as the acquisition of knowledge or a skill through study, experience or instruction. Enterprises must recognize that people operate and communicate through learning that includes the social processes of collaborating, sharing knowledge and building on each other's ideas. Managers must recognize that knowledge resides in people, and knowledge creation occurs in the process of social interaction and learning."

When businesses downsize, the remaining staff can do nothing but 'muddle through', knowledge is lost despite a company's best efforts to retain staff, but the market notices that lay-offs may indicate a deeper issue than merely cost cutting (Gayton, 2008). Organization seems a team, procedures are like teamwork. Therefore, through the activities, ethical learning can be a good method for employees to have practice in behaving ethically. 
Another way of implementing of the code of ethics is by way of regular monitoring by the government of the concerned country. For the smooth running of the monitoring activity, government can set up a monitoring department. The officers of this department will be responsible for regular monitoring on the business organizations for implementation of the code of business ethics.

We cannot leave the implementation of ethics to the business organization alone, because some of the contents of ethics may conflict with the interest of the business organizations or business organizations may think of bypassing the ethics to maximize profit in the organization. Therefore, business organizations will be asked to monitor the implementation of the code of business ethics, and at the same time the concerned government department will also intensify monitoring of the implementation of the code of business ethics. In this way we may make sure the code of business ethics is properly implemented.

\section{Business Ethical Model}

Business ethical model 1 in the Appendix explains that every business organization must have a code of business ethics and the code must specify the contents of ethics. These ethical contents are crucial for every business organization, because the implementation and practice of the ethical contents can ensure customer satisfaction and loyalty. When customers are satisfied, they will buy more and more products from the business organization and as a result the profit will increase. Therefore, it is very important to have a code of business ethics and to implement it in the business organization properly. Thus, the proper implementation of business ethics can guarantee customer satisfaction and profitability in the business.

In business ethical model 2 in the Appendix, we can see, in a company or organization ethical practice can be maintained if there is either strong code of ethics which is strongly applied, or the value of Islamic work ethics is well concerned among employees. For a bureaucratic organization, the strong code of ethics is accelerated from the top management that creates an ethical workplace environment. However, ethical practice generates customer satisfaction for internal customers as well as external customers. Internal customers are the employees of the organization such as employees from other departments who are considered as internal customers and principally they break down departmental barriers. If internal customers are happy and satisfied with the ethical practice within the organization, they will think that they are treated equally and that there is no discrimination in the organization. Fundamentally, this type of thinking and feelings ensure the proper rights of the employees and finally they feel satisfied. Unlike internal customers, external customers may not be a part of the organization, but they are affected by the organization's actions. They can be defined as those who purchase, use and influence the sale of the product or service.

The perception of external customers is very important for the organization in the sense that how they perceive the organization is strongly influenced by the organization's ethical values whereby ethical value is a significant part of company's image in the business world. By the same way, once they are satisfied with the ethical practice by the organization itself, they become satisfied. There are a lot of things that affect customer satisfaction but ethical practice is considered as vital for customer satisfaction. Actually, internal and external customer satisfaction makes overall customer satisfaction which produces customer loyalty. Once customers become loyal, they are considered as permanent customers of the organization. In reality, customers are 'the king' for a company or organization. An increase in customers boosts sales and revenue, and more revenue means more profit. Therefore, ethical practice ultimately generates profitability and constructive organization performance.

\section{Conclusion and recommendation}

This paper has identified that ethical practices and the proper implementation of ethical practices are very important for organizational goodwill. It is also noticeable that an ethical organization's employees are more satisfied and loyal to the company than those of an unethical one. With strong ethical enforcement, companies can build long term profitable relationships with their stakeholders. On the other hand, a good number of cases of unethical practices are being reported each year all over the world. The reason might be the wrong implementation and communication of ethical standards. By nature, human beings are greedy. So it is not possible to completely remove unethical practices. But it can be minimized through continuous reminders. In the present business atmosphere, there are some organizations that are ethical and in some organizations ethics are not practiced as rationally expected. Despite this type of mixed attitude towards business ethics, it can be said that ethical trend will change an organization's internal and external reputation. In future, ethical considerations will move from individual awareness to organizational practice for the purpose of better business strategy.

It is significant to have a code of business ethics for each and every company and the corporate managers must adopt appropriate means to implement the contents of that code of business ethics. There should have adequate emphasis on the implementation of the code of business ethics in business organizations. To have a proper code of 
business ethics and to undertake effective method of implementing business ethics can ensure success in the business organization as well as to the society where it operates. Proper implementation of business ethics can ensure satisfaction of all stakeholders of the business organization. It is the ultimate desire of all stakeholders of a business organization that it will implement its code of business ethics in the true sense. Future research may be conducted in this area as this is a significant area of business environment.

\section{References}

Beauchamp, T.L., Bowie, N.E. and Arnold, D.G. (2009). Ethical Theory and Business, Australia, New Jersy: Pearson, Prentice Hall, eighth edition.

Bixler, C. (2002). “Applying the four pillars of knowledge management," KM World, 11(1): 10-20.

Blumberg, P.I. (1970). "Corporate Responsibility and the Social Crisis”, Boston University Law Review, 50: 157175 .

Boone, Louis E and Kurtz, David L. (2005). Contemporary Business, UK: Thomson, SouthWestern Publisher.

Brenkert, G.G. (2010). The Oxford Handbook on Business Ethics, Oxford: Oxford University Press.

Brenkert, G.G. (2010). Marketing Ethics, UK: Blackwell Publishers.

Brickley, J.A., Clifford, W.S. Jr and Zimmerman, J.L. (2002). "Business ethics and organizational architecture," Journal of Banking and Finance, 26: 1821-35.

Carasco, E.F. and Singh, J.B. (2003). "The content and focus of the codes of ethics of the world's largest transnational corporations", Business and Society Review, Vol. 108, pp. 71-94.

Carroll, A.B. (1991). The Pyramid of Corporate Social Responsibility: Toward the Moral Management of Organizational Stakeholders, London: Business Horizons.

Companies Commission Malaysia. (2008). Code of Ethics for Company Directors, Kuala Lumpur, Malaysia: Companies Commission Malaysia. See, http://www.ssm.com.my/en/services_code.php

Consume Protection Act 2006 (Bangladesh)

Consumer Protection Act 1999 (Malaysia)

Darwish, A. Yousef. (1999). "Islamic work ethic: A moderator between organizational commitment and job satisfaction in a cross-cultural context," Personnel Review, 30(2): 152-169.

David, F. (1989). Strategic management. Columbus: Merrill Publishing Company.

David, F. R. (1991). Strategic Management, New York: Merrill.

David, F.R. and David, R.F. (2009), Strategic Management: Concepts and Cases, London: Pearson Education.

De Gorge, R.T. (2010). Business ethics, Upper Saddle River, N.J.: Pearson, Prentice Hall.

Desjardins, Josheph. (2009). An Introduction to Business Ethics, London: McGraw Hill.

Ebrahim, M.S. (2008). "The financial crisis: comments from Islamic perspectives," IIUM Journal of Economics and Management 16(2): 111-118.

Fisscher, O. and Nijhof, A. (2005). "Implications of business ethics for quality management". The TQM Magazine, 17(2): $150-160$.

Freeman, R.E. and Gilbert, D.E. (1988). Corporate Strategy and the Search for Ethics, UK: Prentice Hall.

Fukukawa, Kyoko. 2010. Corporate social responsibility in Asia, New York: Routledge.

Garrett, T. (1970). Business Ethics, London: Prentice Hall.

Gayton, M. C. (2008). "Business ethics, restrictions on employment and knowledge management," The Journal of Information and Knowledge Management Systems, 38(2): 174-183.

Ghillyer, Andrew. (2010). Business ethics: a real world approach, Boston: McGraw-Hill Higher Education.

Hian, C. K. and Elfred H.Y. Boo. (2004). "Organizational ethics and employee satisfaction and commitment," Management Decision, 42(5): 677-693.

Holme C. (2008), "Business ethics - Part Two: Making it part of your strategy," Industrial and commercial training vol. 40 NO. 6, 2008, pp. 248-252

Joyner, B.E. and Payne, D. (2002), "Evolution and implementation: a study of values, business ethics and corporate social responsibility", Journal of Business Ethics, Vol. 41, pp. 297-311. 
Laczniak, G. 1983, “Business Ethics: A Manager’s Primer”, Business Magazine, January-March, 23-29.

Lamb, Rober \& Boyden. (1984). Competitive strategic management, Englewood Cliffs, NJ: Prentice-Hall.

Lawrence, A.T. (2010). Business and society: Stakeholders, ethics and public policy, New York: McGraw-Hill, IRWIN.

Lindfelt, L. L. (2004), Ethics as Strategy in an Industrial Firm? A Study on the Stora Enso Business Network, Meddelanden fra ${ }^{\circ} \mathrm{n}$ Ekonomisk-Statsvetenskapliga Fakulteten, Fo“retagsekonomiska institutionen, Series A: 540, $\mathrm{A}^{\circ}$ bo Akademis tryckeri.

Leigh, J.H., Lucas, G.H. and Woodman, R.W. (1988), "Effects of perceived organizational factors on role stress-job attitude relationships", Journal of Management, Vol. 14, pp. 41-58.

Machan, T.R. (2009). "Stakeholder Vs. Shareholder theory of ethics of corporate management", International Journal of Economics and Business Research, 1(1), 12-20.

Malin, C.A. (2010). Corporate social responsibility: a case study approach, Northampton, MA: Edward Elgar pub.

Morden, T. (2004), Principles of Management, London: Ashgate Pulishing.

Mukherjee, K. (2009). Principles of Management and Organizational Behaviour, New Delhi: Tata McGraw Hill.

Pettinger, R. (2007). Introduction to Management, London: Palgrave Macmillan.

Pheng and Detta. (2009). Business Law, Oxford, New York: Oxford University Press.

Pramanaik, A. (1994), "The role of family as an institution in materializing the ethico-economic aspects of human fulfillment”, Humanomics, Vol. 10 No. 3, pp. 85-110.

Rahman, A.R. (1996), "Administrative responsibility: an Islamic perspective”, American Journal of Islamic Social Sciences, Vol. 3 No. 4, pp. 497-517.

Render, B. and Stair, R.M. (1992). Introduction to Management Science, Boston, MA: Allyn and Bacon.

Rizk, R. R. (2008). "Back to basics: an Islamic perspective on business and work ethics", Social Responsibility Journal, 4(2): 246-254.

Schemerhorn, J.R. (2009). Introduction to Management, London: John Wiley and Sons.

Sealy, L.S. (1987). "Directors' wider responsibilities- problems: conceptual practical and procedural”, Monash University Law Review, 13, 164-180.

Sealy, L.S., (2001), Cases and Materials in Company Law, UK: Butterworths, Seventh edition.

Siddiqi, M.N. (2008). "The current financial crisis and Islamic Economics," IIUM Journal of Economics and Management, 16(2):125-132.

Solomon, R.C. (1984). Morality and the Good Life, UK: Peason.

Stanwick, P.A. (2009). Understanding Business Ethics, Canada, London: Prentice Hall.

Stodder, G.S. (1998). “Goodwill Hunting,” Entrepreneur, 7: 118-121.

Velasquez, M.G. (2009). Business Ethics: Concepts and Cases, New York: Prentice Hall.

Vitell, S.J., Paolillo, G.P. and Thomas, J.L. (2003). "The perceived role of ethics and social responsibility: a study of marketing professionals," Business Ethics Quarterly, 13: 63-86.

Waddock, S. A., Bodwell, C. and Graves. S.B. (2002). "Responsibility: The New Business Imperative", The Academy of Management Executive, 132-147

Weihrich, H. and Koontz H. (1994). Management: A Global Perspective, New York: Prentice Hall.

Whitehead, M. (1998). "Employee happiness levels impact on the bottom line." People Management, 4:14- 29.

Notes

Note: I am grateful to anonymous reviewers for their valuable comments on my article. Certainly the comments have upgraded the standard of my article. 


\section{Appendix}

Business Ethical Model 1

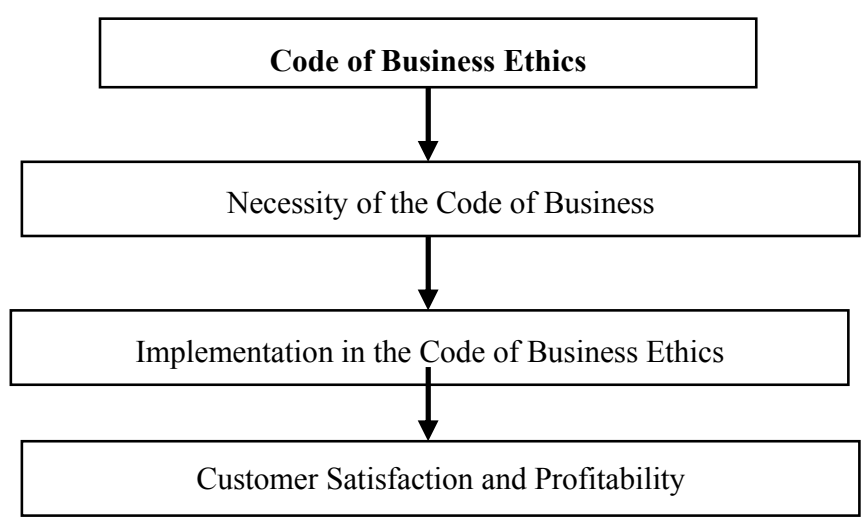

$\underline{\text { Business Ethical Model } 2}$

Ethical Practice, Customer Satisfaction and Customer Loyalty

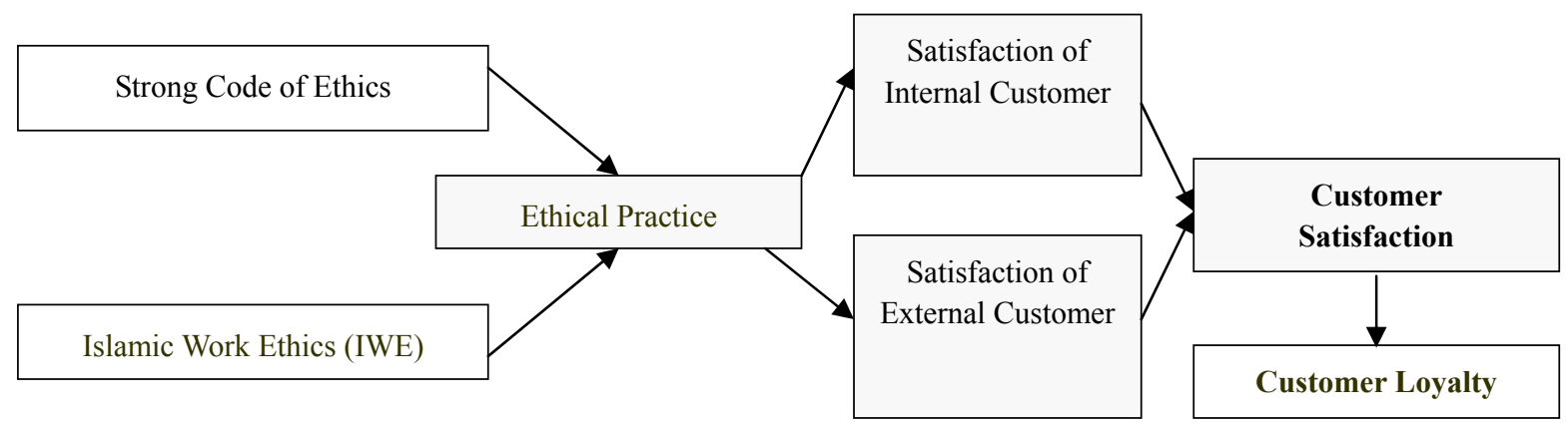

